\title{
REVOLTAS PROVINCIAIS: TESTEMUNHOS POÉTICOS
}

\author{
Vagner Camilo
}

Apesar da extensão do debate no campo da história social e política a propósito da sequência das revoltas que assolaram as províncias brasileiras de norte a sul do país, desde o período da Regência até o Segundo Reinado, e da violenta ação do Estado imperial no movimento de repressão, pouco se tem refletido a respeito de sua repercussão na produção literária que lhe foi contemporânea ou imediatamente posterior aos levantes.

Não fossem raros estudos como o de Jamil Almansur Haddad, sobre Castro Alves e a Revolução Praieira, ou, mais recentemente, o livro de David Treece, sobre o indianismo romântico, em que sustenta a tese de o antilusitanismo de fundo da poesia de um Gonçalves Dias ter raízes no contexto de tais revoltas provinciais, quase nada se teria falado sobre o tema na historiografia e na crítica literárias, notadamente quando se trata de um gênero como a poesia. ${ }^{1}$

Nesta seção da Revista Teresa, optou-se por reproduzir uns poucos exemplos de poemas - uns bem mais conhecidos, outros não - sobre algumas dessas revoltas. Uma pesquisa detida permitiria revelar um número bem mais representativo de testemunhos poéticos envolvendo esses episódios históricos.

O primeiro aqui reproduzido é de Gonçalves Dias, que conheceu muito de perto, em sua província natal, uma dessas revoltas provinciais: a Balaiada (1838-1841), abordada nos versos por imagens apocalípticas similares àquelas com que ele descreve o trauma da Conquista. O poema em questão é “O Morro do Alecrim”, que só apareceu na primeira edição do seu livro de estreia, Primeiros cantos, sendo, nas edições seguintes, em parte suprimido, em parte desdobrado em dois outros poemas bastante lembrados: "Caxias" e "Deprecação".

$\mathrm{Na}$ sua versão original, o poema rememora a destruição das comunidades tupis quando da chegada do colonizador português numa batalha encenada no morro que dá

\footnotetext{
1. TREECE, David. Exilados, aliados, rebeldes: o movimento indianista, a política indigenista e o Estado-nação imperial. São Paulo: Edusp/Nankim, 2008. Alfredo Bosi sustenta a mesma tese, de passagem, em "Um mito sacrificial: o indianismo de Alencar”. Dialética da colonização. São Paulo: Companhia das Letras, 1992, pp. 176-93.
} 
título ao poema, situado na província natal do poeta. O mesmo morro, que guarda ainda as marcas do sangue derramado pelos índios no vermelho da terra, segundo os versos, seria, séculos depois, palco da Balaiada, mesclando assim o sangue dos revoltosos com o dos primeiros habitantes do território. Os versos suprimidos nas edições seguintes são justamente os que estabelecem essa associação. No contexto da época, decerto, seria bastante arriscado dar forma literária a uma revolta que questionava o poder central e expunha a violência de sua ação repressora sobre os revoltosos. Afinal, o discurso oficial que se construiu em torno das revoltas regenciais tendia a caracterizá-las como manifestações de rebeldes, de arruaceiros, que só ocorreram mesmo devido à ausência de um monarca no trono. Disso não esteve longe nem Gonçalves de Magalhães, no relato sobre a Balaiada, que produziu quando secretariou o coronel Lima (futuro duque de Caxias) no Maranhão. ${ }^{2}$

É possível que uma das razões da supressão de versos e desdobramento do "Morro do Alecrim" em dois outros poemas fosse a integração crescente de Gonçalves Dias ao corpo de regime, vivendo uma contradição bastante conhecida pelos intelectuais brasileiros que muitas vezes se viram numa situação de dependência e favor em relação a um poder central cuja ideologia frequentemente condenavam. Essa dependência, entretanto, não foi suficiente para romper de todo o vínculo de seu pró-indianismo liberal com a cena política em que foi gestado.

O segundo poema reproduzido nesta seção é o de Álvares de Azevedo sobre o líder militar da Insurreição Praieira (1848-1850), no qual o sopro mais forte de liberalismo somado ao sentimento patriótico do poeta se faz sentir no compasso épico desses conhecidos versos. ${ }^{3}$ A Pedro Ivo, com sua "alma cheia de fogo e mocidade", vão se identificar o eu azevediano e a mocidade acadêmica de seu tempo, que, por tabela, se solidarizavam da causa daqueles liberais-radicais que eram denominados pelos conservadores, num dos jornais de época da província paulistana, como "os comunistas do Norte, copiadores dos excessos da Comuna de Paris em 1848”. Como nota Raimundo

2. GONÇAlves de magalhães, Domingos José. A revolução na província do Maranhão desde 1839 a 1840. São Luís: Tipografia do Progresso, 1858.

3. Retomo aqui, brevemente, o comentário sobre o poema já feito em um estudo sobre Álvares de Azevedo e o pensamento liberal de seu tempo: CAmilo, Vagner. "Álvares de Azevedo, o Fausto e o mito romântico do adolescente no contexto político-estudantil do segundo reinado". Itinerários, Araraquara, n. 33, jul./dez. 2011, pp. 61-108. 
Magalhães Júnior, a compaixão pelo triste destino do herói liberal se mescla nos versos azevedianos à indignação com o reacionarismo e com a fraqueza do Império. ${ }^{4}$

No poema, ao mesmo tempo que interpela diretamente Pedro II advogando o perdão imperial em favor do líder pernambucano, justamente no momento em que se discutia o rigor da anistia a Pedro Ivo, Álvares de Azevedo atacava violentamente os conservadores não só pela ação repressora em relação aos praieiros, que desencadeou a revolta provincial, mas pela submissão vergonhosa aos ingleses, comprometendo a soberania nacional, no conhecido episódio do navio por estes aprisionado em águas brasileiras, sob suspeita de tráfico negreiro, valendo-se do amparo legal do Bill Aberdeen. Em ambos os casos, como se pode perceber nos versos, o que está em jogo é o orgulho patriótico ou nacional.

Operando no duplo registro antitético caro ao Romantismo, ao mesmo tempo que eleva a imagem do líder praieiro à esfera do sublime (pois, com sua fronte erguida e laureada, é gênio das pelejas comparado ao leão sangrento que ruge e à águia nunca vencida), Álvares de Azevedo rebaixa a facção inglória e ímpia do partido conservador então no poder, com seu sangue impuro e boca maldita, ao plano do grotesco, equiparando-o a um verme no chão da tumba escura, por prostituir a pátria (Como torpe, despida Messalina/ aos apertos infames do estrangeiro/ traficam dessa mãe que os embalou)...

Em diálogo direto com Álvares de Azevedo, evocado em epígrafe, outro poema conhecido sobre o líder da Praieira é o de Castro Alves. O confronto entre ambos os poemas, aliás, pode ser instigante pelo que revelam de afinidades e diferenças, dentre as quais não parece incluir-se a que supõe Edison Carneiro quando afirma que, no primeiro, teríamos a visão de um monarquista, ao passo que, no segundo, já vibrava o pensamento republicano... ${ }^{5}$ Disso, aliás, já havia divergido Haddad quando afirma que não poderia ser tachado, sem mais, de monarquista um poema em que o herói é exaltado como "filho do povo"...

Detendo-se, entretanto, em Castro Alves, nota Haddad que a Praieira inspirou o poeta baiano mais até do que a Guerra do Paraguai e que, na revolta pernambucana, sua lira ficou, evidentemente, "ao lado dos cavalgados contra todos os Cavalcantis opressores; ao lado do nacional pauperizado em contraposição ao 'marinheiro' parasitário

\footnotetext{
4. Magalhães júnior, Raimundo. Poesia e vida de Álvares de Azevedo. São Paulo: Editora das Américas, 1962.

5. CARneiro, Edison. Trajetória de Castro Alves. Rio de Janeiro: Editorial Vitória, s. d., p. 41.
} 
e enriquecido; ao lado dos pardos do Recife contra os brancos, às vezes azulecidos de sangue holandês e encastelados nos engenhos". ${ }^{6}$ Lembra, ainda, que a visão de Castro Alves é produto da "atmosfera pernambucana, impregnada das emanações das sociedades secretas do tipo maçônico, as primeiras, pelo consenso mais geral, que se instalaram no Brasil, e em cujos recintos indevassáveis iam sendo ensinados os 'mistérios' da Democracia." ' Haddad chama a atenção ainda para o fato de que o tribuno Borges da Fonseca, espécie de mentor ideológico da Revolta Praieira, teve uma presença importante, mas ainda não devidamente esclarecida, na vida de Castro Alves (que chegou a escrever para o periódico daquele).

A Revolta Praieira inspirou outros tantos poetas, que fizeram ecoar, no plano da alta literatura, o mesmo espírito dominante na poesia popular do tempo, sintetizado na famosa quadrinha:

\section{Machado que corta lenha \\ Também corta mulungu; \\ Praieiro que tem vergonha \\ Não fala com guabiru.}

Dentre esses poetas, vale lembrar Nísia Floresta e Pedro Luís. No caso da primeira, a revolta pernumbacana é evocada em associação estreita com o indianismo, tal como fizera Gonçalves Dias no caso da Balaiada. Vem, aliás, de Gonçalves Dias, notadamente de Os timbiras, a inspiração épica para A lágrima de um caeté, que supõe-se tenha sido censurado pelo governo imperial, já que é notório nos versos que ela se colocava favoravelmente ao lado dos revoltosos, manifestando sua aspiração republicana. ${ }^{8}$ Nele, a poetisa potiguar celebra não mais Pedro Ivo, mas a saga de outro mártir da Praieira: Nunes Machado, tido como descendente dos caetés, que acaba por morrer em combate. A revolução provincial pernambucana é, assim, relacionada a um anseio vindicativo

6. HAdDAD, Jamil A. "Castro Alves e a Revolução Praieira". Revista de História, Rio de Janeiro, v. 6, n. 13, p. 211, 1953.

7. Ibid.

8. Retomo aqui parte dos comentários de Alessandra da Silva Carneiro sobre o poema nisiano, em dissertação inédita: Do tatu fúnebre ao lar-titú. Implicações do indianismo no canto segundo do poema $\mathrm{O}$ guesa, de Sousândrade. São Paulo: FFLCH/USP, 2011. 
pela matança de índios desde a Conquista, concebido pelo mesmo sentimento antilusitanista que nutriu a poesia de Gonçalves Dias.

Dada a extensão dessa que ficou conhecida como a Poesia sobre a Revolução Praieira, não foi possível reproduzi-la aqui. ${ }^{9}$ Em vez dela, optou-se pelo poema de Pedro Luís, que também preferiu tratar da Praieira por meio da celebração de Nunes Machado.

A estratégia dramática que não dispensa recursos góticos (não só no retrato do herói, mas também no cenário de sua aparição) é a do fantasma do herói morto em batalha que irrompe em meio ao cenário sinistro para reivindicar a perpetuação dos ideais libertários por que ele lutou e morreu. A sua figura elevada, por lugares-comuns do sublime, ao estatuto de semideus, permite aproximar sua história de episódios mitológicos (como a do gigante Anteu no deserto, símbolo da força espiritual mantida pela fé nas coisas factuais, terrenas) e bíblicos, como o narrado no Êxodo 13, sobre a partida dos israelitas de Sucote, acampando em Etã, junto ao deserto, quando Deus se converte, diante deles, numa coluna de nuvem, para guiá-los no caminho e, de noite, numa coluna de fogo, a fim de iluminá-los e, desse modo, poderem caminhar o tempo todo. Nunes Machado é comparado a essa coluna de fogo, guiando aqueles que anseiam pela liberdade contra um regime opressor para não se perderem no deserto e para seguirem em direção à terra da promissão.

Por último, caminhando do norte e nordeste ao extremo-sul do país, foram escolhidos dois poemas anônimos que envolvem a Revolução Farroupilha (1835-1845). ${ }^{10}$ Os dois poemas se complementam num diálogo agressivo entre os antagonistas (farrapos $x$ “caramurus") envolvidos na refrega, lançando mão dos mesmos artíficios retóricos, que incluem a configuração do poema como persignação, forma de esconjuro ou sinal de proteção contra o adversário demonizado nos versos. A invectiva que parte de um lado configura as forças imperiais como despóticas, ao passo que, da outra parte, os revolucionários são tidos como homens sem lei nem religião, aos quais só cabia mesmo a velha tortura militar com as armas (tornilho).

Seguem, assim, os seis poemas selecionados, com vistas a estimular novas pesquisas de outros testemunhos literários (e não só poéticos) dessas e de outras revoltas não evocadas aqui.

9. A edição mais recente de que se tem notícia é: FLORESTA, Nísia. A lágrima de um caeté (edição atualizada com notas e estudo crítico de Constância Lima Duarte). Natal: Fundação José Augusto, 1997. 10. A sugestão desses dois poemas é de Maria Eunice Moreira, a quem registro aqui meus agradecimentos. 


\section{Morro do Alecrim}

Gonçalves Dias

I.

Caxias, como és bela! - no deserto,

Entre montanhas, derramada em vale

De flores perenais,

És qual tênue vapor que a brisa espalha

No frescor da manhã meiga soprando

À flor de manso lago.

Tu és a flor que despontaste livre

Por entre os troncos de robustos cedros,

Forte - em gleba inculta;

És qual gazela que o deserto educa

No ardor da sesta debruçada exangue

À margem da corrente.

Não tens em mole seda oculto as graças,

Não cinges d'oiro a fronte que descansas

Na base da montanha;

És bela como a virgem das florestas,

Que vê nas águas desenhar-se as formas,

Firmada em tronco anoso.

Que monte além se eleva negrejante!

$\mathrm{Na}$ areia a base enterra, e o dorso ingente

De rija pedra mosqueado amostra;

Estéril como ele é, dizer parece

Que a ira do Senhor ardendo em raios

A seve d'hartos troncos - de mil anos

Apagou - consumiu - num breve instante. 
Mas não; a rubra cor que aí se enxerga

É sangue que correu;

Cada pedra que i jaz encerra a história

D'um bravo que morreu.

E raios mil de guerra em morte envoltos

Já lá do cimo agreste da montanha

Sibilando e gemendo à funda base

Baixaram sussurrando.

É do povo o Sinai, que o nobre sangue

Independente e forte - em lide acesa

$\mathrm{Na}$ arena derramou;

E o filho inda lá vai cheio de orgulho,

Do pai beijando o sangue em largos traços

Que a pedra conservou.

II.

E quando alva lua no céu vai brilhando

O disco formoso luzente mostrando,

Então quando as ondas mais vívidas crescem

E mais contra a praia a bramir se enfurecem;

Descendo das nuvens ao monte orgulhoso

Infausta se amostra sinistra figura,

Mais negra que as trevas, que fora pasmoso

Ser esse fantasma de humana natura.

E quando é que se vê? - Quando nos bosques

A flor mais puro seu perfume exala,

Quando nas folhas o sussurro morre,

Quando das aves o gorjeio para. 
Quando imundo tatu na concha envolto

Vai de manso volver minada campa,

E a coruja sedenta a luz dos mortos

No fronteiro pano da muralha estampa.

Desde quando aparece? - Ninguém sabe,

E talvez apareça sem ter fim;

Só um em cujo peito horror não coube

Já do fantasma a voz ouviu assim.

Manitôn ${ }^{11}$ Manitô - cobriste o teu rosto

Com denso velâmen de penas gentis;

E jazem teus filhos clamando vingança

Dos bens que lhes deste da perda infeliz!

Manitô - Manitô - descobre o teu rosto,

Bastante nos pesa da tua vingança;

Já lágrimas tristes choraram teus filhos,

Teus filhos que choram tão grande mudança.

O triste Anhangá de mui longe nos trouxe

Filhos de Tupã, essa raça danada,

Em vão deu-Ihe of'rendas o Piaga divino

Tocando a maraca na dança sagrada.

Em vão neste monte lhe veio ofertar

A pel'maculada de tigre raivoso,

E frutos, e frutas - e a pel'cambiante

Da Boa vistosa de corpo pasmoso.

11. Variantes: manitó ou manitu (cf. Houaiss e Caldas Aulete).

142 - CAMILO, Vagner. Revoltas provinciais: testemunhos poéticos 
Manitô - Manitô - cobriste o teu rosto

Com denso velâmen de penas gentis;

E jazem teus filhos clamando vingança

Dos bens que lhes deste da perda infeliz.

Teus filhos valentes, temidos na guerra, No albor da manhã quão fortes que os vi! A morte pousava nas plumas da frecha, No gume da maça, no arco tupi.

E hoje em que apenas a enchente do rio Cem vezes hei visto crescer - abaixar... Já restam bem poucos dos teus qu'inda possam Dos seus, que já dormem, os ossos levar.

Teus filhos valentes causavam terror[.] Teus filhos enchiam as bordas do mar, As ondas coalhavam de estreitas igaras De frechas cobrindo os espaços do ar.

Já hoje não caçam nas matas tão suas A corça ligeira - o trombudo coati. A morte pousava nas plumas da frecha, No gume da maça - no arco tupi.

O Piaga nos disse que breve seria, Manitô, dos teus a cruel punição; E os teus inda vagam por serras, por vales, Buscando um asilo por ínvio sertão! 
Manitô - Manitô - descobre o teu rosto,

Bastante nos pesa da tua vingança;

Já lágrimas tristes choraram teus filhos,

Teus filhos que choram tão grande tardança. ${ }^{12}$

12. Gonçalves dias, Antônio. Primeiros cantos. Poesias de... Rio de Janeiro: Casa de Eduardo e Henrique Laemmert, 1846, pp. 24-9. Consulta feita ao acervo digital da Biblioteca Brasiliana Guita e José Mindlin (www.brasiliana.usp.br). 


\section{Pedro Ivo}

Álvares de Azevedo

Tristes coroas, sob as quais às vezes

Está gravada uma inscrição d'infâmia !

...... Alexandre Herculano

Perdoai-Ihe, Senhor! ele era um bravo!

Fazia as faces descorar do escravo

Quando ao sol da batalha a fronte erguia,

E o corcel gotejante de suor

Entre sangue e cadáveres corria!

O gênio das pelejas parecia...

Perdoai-Ihe, Senhor!

Onde mais vivo em peito mais valente

N'um coração mais livre o sangue ardente

Ao fervor desta América bulhava?

Era um leão sangrento que rugia:

Da guerra nos clarins se embriagava. -

E vossa gente - pálida recuava

Quando ele aparecia!

Era filho do povo - o sangue ardente

Às faces lhe assomava incandescente

Quando cismava do Brasil na sina...

Ontem - era o estrangeiro que zombava,

Amanhã - era a lâmina assassina,

No cadafalso a vil carnificina

Que em sangue jubilava! 
Era medonho o rubro pesadelo

Mas nas frontes venais do gênio o selo

Gravaria o anátema da história!

Dos filhos da nação a rubra espada

No sangue impuro da facção inglória

Lavaria dos livres na vitória

A mancha profanada!

A fronte envolta em folhas de loureiro

Não a escondemos, não!... Era um guerreiro!

Despiu por uma ideia sua espada!

Alma cheia de fogo e mocidade,

Que ante a fúria dos reis não se acobarda

Sonhava nesta geração bastarda

Glórias... e liberdade!

Tinha sede de vida e de futuro;

Da liberdade ao sol curvou-se puro

E beijou-lhe a bandeira sublimada:

Amou-a como a Deus, e mais que a vida!

Perdão para essa fronte laureada!

Não lanceis à matilha ensanguentada

A águia nunca vencida!

Perdoai-Ihe, Senhor! Quando na história

Vedes os reis se coroar de glória

Não é quando no sangue os tronos lavam

E envoltos no seu manto prostituto

Olvidam-se das glórias que sonhavam!

Para esses - maldição! que o leito cavam

Em lodaçal corrupto! 
Nem sangue de Ratcliffs o fogo apaga

Que as frontes populares embriaga,

Nem do herói a cabeça decepada

Imunda, envolta em pó, no chão da praça,

Contraída, amarela, ensanguentada,

Assusta a multidão que ardente brada

E tronos despedaça!

O cadáver sem bênçãos, insepulto,

Lançado aos corvos do ervaçal inculto,

A fronte varonil do fuzilado

Ao sono imperial co'os lábios frios

Podem passar no escárnio desbotado -

Ensanguentar-te a seda ao cortinado

E rir-te aos calafrios!

Não escuteis essa facção ímpia

Que vos repete a sua rebeldia...

Como o verme no chão da tumba escura

Convulsa-se da treva no mistério:

Como o vento do inferno em água impura

Com a boca maldita vos murmura:

"Morra! salvai o império!"

Sim, o império salvai: mas não com sangue!

Vede - a pátria debruça o peito exangue

Onde essa turba corvejou, cevou-se!

Nas glórias, no passado eles cuspiram!

Vede - a pátria ao Bretão ajoelhou-se,

Beijou-lhe os pés, no lodo mergulhou-se!

Eles a prostituíram! 
Malditos! do presente na ruína

Como torpe, despida Messalina

Aos apertos infames do estrangeiro

Traficam dessa mãe que os embalou!

Almas descridas do sonhar primeiro

Venderiam o beijo derradeiro

Da virgem que os amou!

Perdoai-Ihe, Senhor! nunca vencido,

Se em ferros o lançaram, foi traído!

Como o Árabe além no seu deserto

Como o cervo no páramo das relvas

Ninguém os trilhos lhe seguira ao perto

No murmúrio das selvas!

Perdão! por vosso pai! que era valente, Que se batia ao sol co'a face ardente,

Rei - e bravo também! e cavaleiro!

Que da espada na guerra a luz sabia

$\mathrm{E}$ ao troar dos canhões entumecia

O peito de guerreiro!

Perdão, por vossa mãe! por vossa glória!

Pelo vosso porvir e nossa história!

Não mancheis vossos louros do futuro!

Nem lisonjeiro incenso a nódoa exime!

Lava-se o poluir de um leito impuro -

Lava-se a palidez do vício escuro -

Mas não lava-se um crime!'3

13. AZEvedo, Álvares de. Obras. Rio de Janeiro: Typographia Universal de Laemmert, 1855, v. 2, pp.360-3. Consulta feita ao acervo digital da Biblioteca Brasiliana Guita e José Mindlin (www.brasiliana.usp.br). 
3. Pedro Ivo

Castro Alves

\author{
Sonhava nesta geração bastarda \\ Glórias e liberdade!... \\ Era um leão sangrento, que rugia, \\ Da glória nos clarins se embriagava, \\ E vossa gente pálida recuava, \\ Quando ele aparecia.
}

\title{
Álvares de Azevedo
}

I.

Rebramaram os ventos... Da negra tormenta

Nos montes de nuvens galopa o corcel...

Relincha - troveja... galgando no espaço

Mil raios desperta co'as patas revel.

É noite de horrores... nas grunas celestes,

Nas naves etéreas o vento gemeu...

E os astros fugiram, qual bando de garças

Das águas revoltas do lago do céu.

E a terra é medonha... As árvores nuas

Espectros semelham fincados de pé,

Com os braços de múmias, que os ventos retorcem,

Tremendo a esse grito, que estranho lhes é.

Desperta o infinito... Co'a boca entreaberta

Respira a borrasca do largo pulmão.

Ao longe o oceano sacode as espáduas

- Encélado novo calcado no chão. 
É noite de horrores... Por ínvio caminho

Um vulto sombrio sozinho passou,

Co'a noite no peito, co'a noite no busto

Subiu pelo monte, - nas cimas parou.

Cabelos esparsos ao sopro dos ventos,

Olhar desvairado, sinistro, fatal,

Diríeis estátua roçando nas nuvens,

P'ra qual a montanha se fez pedestal.

Rugia a procela - nem ele escutava!...

Mil raios choviam - nem ele os fitou!

Com a destra apontando bem longe a cidade,

Após largo tempo sombrio falou!...

II.

Dorme, cidade maldita,

Teu sono de escravidão!...

Dorme, vestal da pureza,

Sobre os coxins do Sultão!...

Dorme, filha da Geórgia,

Prostituta em negra orgia

Sê hoje Lucrécia Bórgia

Da desonra no balcão!...

Dormir?!... Não! Que a infame grita

Lá se alevanta fatal..

Corre o champagne e a desonra

Na orgia descomunal...

Na fronte já tens um laço...

Cadeias de ouro no braço,

De pérolas um baraço,

- Adornos da saturnal! 
Louca!... Nem sabes que as luzes,

Que acendeu p'ra as saturnais,

São do enterro de seus brios

Tristes círios funerais...

Que o seu grito de alegria

É o estertor da agonia,

A que responde a ironia

Do riso de Satanás!...

Morreste... E ao teu saimento

Dobra a procela no céu.

E os astros - olhar dos mortos -

A mão da noite escondeu.

Vê!... Do raio mostra a lampa

Mão de espectro, que destampa

Com dedos de ossos a campa,

Onde a glória adormeceu.

E erguem-se as lápidas frias,

Saltam bradando os heróis:

["]Quem ousa da eternidade

Roubar-nos o sono a nós?["]

Responde o espectro: ["]A desgraça!

Que a realeza, que passa,

Com o sangue de vossa raça,

Cospe lodo sobre vós!...["]

Fugi, fantasmas augustos!

Caveiras que coram mais

Do que essas faces vermelhas

Dos infames párias!...

Fugi do solo maldito...

Embuçai-vos no infinito!...

E eu por detrás do granito

Dos montes ocidentais... 
Eu também fujo... Eu fugindo!...

Mentira desses vilões!...

Não foge a nuvem trevosa

Quando em asas de tufões,

Sobe dos céus à esplanada,

Para tomar emprestada

De raios uma outra espada,

À luz das constelações!...

Como o tigre na caverna

Afia as garras no chão,

Como em Elba amola a espada

Nas pedras - Napoleão,

Tal eu - vaga encapelada,

Recuo de uma passada,

P'ra levar de derribada

Rochedos, reis, multidões...!

III.

"Pernambuco! Um dia eu vi-te

Dormido imenso ao luar,

Com os olhos quase cerrados,

Com os lábios - quase a falar

Do braço o clarim suspenso,

- O punho no sabre extenso

De pedra - recife imenso,

Que rasga o peito do mar...

E eu disse: Silêncio, ventos!

Cala a boca, furacão!

No sonho daquele sono

Perpassa a Revolução!

Este olhar que não se move

'Stá fito em - Oitenta e Nove -

Lê Homero - escuta Jove...

- Robespierre - Dantão. 
Naquele crânio entra em ondas

O verbo de Mirabeau...

Pernambuco sonha a escada

Que também sonhou Jacó;

Cisma a República alçada,

E pega os copos da espada,

Enquanto em su'alma brada:

"Somos irmãos, Vergniaud".

Então repeti ao povo:

- Desperta do sono teu!

Sansão - derroca as colunas!

Quebra os ferros - Prometeu!

Vesúvio curvo - não pares,

Ígnea coma solta aos ares,

Em lavas inunda os mares,

Mergulha o gládio no céu.

República!... Voo ousado

Do homem feito condor!

Raio de aurora inda oculta,

Que beija a fronte ao Tabor!

Deus! Por qu'enquanto que o monte

Bebe a luz desse horizonte,

Deixas vagar tanta fronte,

No vale envolto em negror?!...

Inda me lembro... Era, há pouco,

A luta!... Horror!... Confusão!...

A morte voa rugindo

Da garganta do canhão!...

O bravo a fileira cerra!...

Em sangue ensopa-se a terra!...

E o fumo - o corvo da guerra -

Com as asas cobre a amplidão... 
Cheguei!... Como nuvens tontas,

Ao bater no monte - além,

Topam, rasgam-se, recuam...

Tais a meus pés vi também

Hostes mil na luta inglória...

...Da pirâmide da glória

São degraus... Marcha a vitória,

Porque este braço a sustém.

Foi uma luta de bravos,

Como a luta do jaguar,

De sangue enrubesce a terra,

- De fogo enrubesce o ar!...

... Oh!... mas quem faz que eu não vença?

- O acaso... - avalanche imensa,

Da mão do Eterno suspensa,

Que a ideia esmaga ao tombar!...

Não importa! A liberdade

É como a hidra, o Anteu.

Se no chão rola sem forças,

Mais forte do chão se ergueu...

São os seus ossos sangrentos

Gládios terríveis, sedentos...

E da cinza solta aos ventos

Mais um Graco apareceu!...

Dorme, cidade maldita!

Teu sono de escravidão!

Porém no vasto sacrário

Do templo do coração,

Ateia o lume das lampas,

Talvez que um dia dos pampas

Eu surgindo quebre as campas

Onde te colam no chão. 
Adeus! Vou por ti maldito

Vagar nos ermos pauis.

Tu ficas morta, na sombra,

Sem vida, sem fé, sem luz!...

Mas quando o povo acordado

Te erguer do tredo valado,

Virá livre, grande, ousado,

De pranto banhar-me a cruz!...

IV.

Assim falara o vulto errante e negro,

Como a estátua sombria do revés,

Uiva o tufão nas dobras de seu manto,

Como um cão do senhor ulula aos pés...

Inda um momento esteve solitário

Da tempestade semelhante ao deus,

Trocando frases com os trovões no espaço

Raios com os astros nos sombrios céus...

Depois sumiu-se dentre as brumas densas

Da negra noite - de su'alma irmã...

E longe... longe... no horizonte imenso

Ressonava a cidade cortesã!...

Vai!... Do sertão esperam-te as Termópilas

A liberdade ainda pulula ali...

Lá não vão vermes perseguir as águias,

Não vão escravos perseguir a ti!

Vai!... Que o teu manto de mil balas roto

É uma bandeira, que não tem rival.

- Desse suor é que Deus faz os astros...

Tens uma espada, que não foi punhal. 
Vai, tu que vestes do bandido as roupas,

Mas não te cobres de uma vil libré

Se te renega teu país ingrato

O mundo, a glória tua pátria é!...

\section{V.}

E foi-se... E inda hoje nas horas errantes, Que os cedros farfalham, que ruge o tufão, E os lábios da noite murmuram nas selvas $E$ a onça vagueia no vasto sertão.

Se passa o tropeiro nas ermas devesas, Caminha medroso, figura-lhe ouvir O infrene galope $d^{\prime} E$ spectro soberbo, Com um grito de glória na boca a rugir.

Que importa se o túm'lo ninguém lhe conhece? Nem tem epitáfio, nem leito, nem cruz?...

Seu túmulo é o peito do vasto universo, Do espaço - por cúpula - as conchas azuis!...

...Mas contam que um dia rolara o oceano

Seu corpo na praia, que a vida Ihe deu...

Enquanto que a glória rolava sua alma Nas margens da história, na areia do céu!...

Recife, Maio de $1865^{14}$

14. Castro Alves, Antônio Frederico de. Espumas fluctuantes: poesias de... Bahia: Typ. de Camillo de Lellis Masson \& Co. 1870, pp. 57-66. Consulta feita ao acervo digital da Biblioteca Brasiliana Guita e José Mindlin (www.brasiliana.usp.br). 
4. Nunes Machado

Pedro Luís

Vai a noite medonha... a lua triste

Rodeada de nuvens cor de sangue,

Lá corre pelo céu,

Como virgem - de amores perseguida

Por demônios horríveis, que procuram

Despedaçar-lhe o véu.

A campina se estende imensa, escura,

$E$ da floresta ao longe na espessura

Braveja o turbilhão!

Quem passasse ouviria a voz dos mortos

Tocar nas folhas e roçar-lhe a face,

Pedindo uma oração.

São horas de sonhar. Pálido e triste,

Um vulto ali de pé murmura e chora...

Que sonhos que ele tem!

Dessa cabeça o negro pensamento

Sabem somente Deus, a lua, o vento

$E$ mais... e mais ninguém.

Junto dele se via denegrida

Lousa funérea tendo à cabeceira

Sinal de redenção!

Passa a noite com todos seus horrores,

Mas não conta o segredo que ali mora,

As cinzas de quem são. 
Mas, de repente, rápido relâmpago

No céu, depois no ar, depois na pedra

Vermelho reluziu...

Quem pode ler o nome do finado

Do relâmpago à luz? - Nunes Machado -

Escrito ali se viu.

E o peregrino, que jazera mudo,

Ouvindo só as notas da tormenta,

Quando o raio vibrou,

Cruzando os braços, alteando a fronte,

Fitou alguns minutos o horizonte...

Depois assim falou:

Este viveu no meio da batalha

E à santa liberdade se abraçou;

Tinha por voz o estoiro da metralha,

Que palácios e tronos abalou.

Hoje sono fatal dorme o gigante;

Mas ainda vive aqui su'alma errante,

Que o cadáver somente se destrói:

Ela passa gritando - Liberdade!

E os ribombos da grande tempestade

São gemidos que solta o grande herói.

Oh! sombra augusta, sombra veneranda!

Depressa nossa pobre geração!

Ela chamou de vil e de nefanda

À bandeira que erguias nessa mão.

Lá nos campos escuros do passado

Tua figura está, Nunes Machado,

Tão grande como é grande um semideus!

Eles querem manchar-te o nobre vulto;

Mas tu deves te rir; calcar o insulto:

O gigante desdenha os pigmeus. 
Eles querem que se rasgue da história

Essa folha - epopeia do valor! -

São blasfêmias: um cântico de glória

Há de sempre seguir ao lidador.

Oh! revistam-se embora de mil cores...

Podem de bruços entoar louvores,

Estendendo o tapete ao pé do rei;

Mas não queiram cuspir do herói na face,

Pois, se a luta algum dia se travasse,

O seu nome talvez marcasse a lei.

A coluna de fogo no deserto

Guiava a raça inteira dos Hebreus;

Sem ela, o caminhar seria incerto,

- Farol aceso pela mão de Deus.

Pesadelo fatal da tirania,

O seu nome também nos alumia,

Dissipa do futuro a cerração;

Mas o povo esqueceu-se dessas lendas,

Levantou no deserto suas tendas,

E não chega ao país da promissão!

Oh! que pesar terrível não oprime

A fronte do Valente sonhador!

Se ele fala, quem fala é a voz do crime,

Cobrem-se os rostos de mortal palor.

E ele passa além cantando um hino,

E murmura pensando no destino:

"Quando é que avistaremos o Sinai?"

E um dia vem que a voz morre no peito,

A terra lhe oferece um frio leito...

E o pobre sonhador soluça e cai!... 
A vingança depois é muito nobre:

São blasfêmias e risos e baldões.

Na terra fria que o cadáver cobre

Não há flores, nem cruz, nem orações.

A raça dos escravos tripudia

Com esse arrojo vil da cobardia,

Mesmo em cima da campa folga e ri...

$E$ às vezes nem sobre ela o povo chora,

Caminha indiferente, vai-se embora,

E não sabe quem é que dorme ali...

Tu, herói, que viveste grande e forte, Sempre cheio de crença no porvir; Tu, que lutaste tanto - até a morte, Sem do peito a esperança sucumbir; Vem dizer aos soldados do futuro Que, se acaso o horizonte está escuro, Nem por isso eles devem vacilar;

Vem dar forças dos bravos à fileira, Que eles hão de seguir tua bandeira, E com ela na frente hão de lutar.

Ele devia vir cheio de glória, De braços estendidos para nós, Avivar-nos o sangue e a memória, Fazendo retumbar a sua voz.

Oh! diante da sombra o mundo pasma; Levanta-te daí, grande fantasma, Envolvido no fúnebre lençol, E mostra à geração que está corruta Como deve lutar, como se luta Com espada valente à luz do sol! 
Levanta-te, vem ver, nobre guerreiro,

O que neste país hoje se faz...

Há de ler algum dia o mundo inteiro:

- Infâmia, perdição - nos seus anais!

$\mathrm{Tu}$, que outrora bradaste furibundo,

À face do Brasil, de todo o mundo,

Pela santa bandeira da nação,

O que fazias hoje, herói sublime,

Se é somente poder - fingido crime,

Liberdade - fingida escravidão!

Ele era imenso, tinha uma esperança;

Era um sonho de glória e de valor!

E ao mesmo tempo um grito de vingança,

Blasfêmia horrível de pungente dor.

Tinha planos também de felicidade;

Mas lembrou-se da pátria e liberdade,

Na peleja medonha se atirou:

Despedaça inimigos, rompe fardas,

Ri do canhão, despreza as espingardas...

Quanto sangue de escravos derramou!...

Ele, louco por nossa liberdade,

Por ela, como um louco, se bateu,

No entanto, - cruel fatalidade!

Por mão de um assassino o herói morreu!

Quanto melhor não fora, na batalha,

Aos gritos pavorosos da metralha,

Sucumbir abraçado ao pavilhão!

Veria o céu azul enfumaçado,

E de sangue e suor todo banhado,

Como um bravo tombara ali no chão! 
Mas não choreis, irmãos; se ele está morto,

A liberdade ainda está de pé!

Como jazer sem vida, sem conforto,

Se é tão viva e brilhante a luz da fé?

Oh! tiranos, o deus da liberdade

Quando cai, não vos pede piedade:

Levanta-se mais forte; é - outro Anteu!

Quando um braço valente cai por terra,

Surgem quarenta prontos para a guerra

Em lugar desse bravo que morreu!!5

15. PEDro Luís. Dispersos. Rio de Janeiro: Civilização Brasileira (Publicações da Academia Brasileira), 1934, pp. 34-40.

162 - CAMILO, Vagner. Revoltas provinciais: testemunhos poéticos 


\title{
5. Persignação Farroupilha
}

\author{
Na coxilha do Seival, ${ }^{16}$ \\ Eu bem o vi muito às pressas \\ Fazer de pronto às avessas \\ Pelo signal \\ Maldito monstro infernal! \\ Não há quem dele dê cabo. \\ Só não entende o diabo \\ Da Santa Cruz! \\ Santo nome de Jesus! \\ Nós todos somos humanos; \\ De semelhantes tiranos \\ Livre-nos Deus. \\ Tanto mal queres aos teus, \\ Que o sangue desejas ver, \\ Pr'a depois vires a ser \\ Nosso senhor? \\ Demais tens visto o rigor, \\ Inimigo da nação, \\ Que produz a boa união \\ Dos nossos.
}

\begin{abstract}
16. Referência ao local onde se deu a batalha do Seival, conflito militar que resultou na proclamação da República Rio-Grandense por Antônio de Sousa Neto e que ocorreu nos campos dos Meneses, cruzando o arroio Seival. A primeira brigada do coronel Neto (destacado por Bento Gonçalves), com quatrocentos homens, atravessou o arroio Seival e encontrou as tropas imperiais sobre uma coxilha, com 560 homens. No embate, os revoltosos saíram vitoriosos, sem nenhuma baixa, ao contrário do que ocorreu com as tropas imperiais.
\end{abstract}


Nós todos somos sócios

Da ordem e patriotismo,

E somos do despotismo

Inimigos.

E tu com os teus amigos,

Caramurus $^{17}$ diabólicos,

Não abram como católicos,

Em nome do Padre.

No entretanto anda o compadre

Do compadre dividido,

Foge da esposa o marido

E do filho[.]

Ó grande Deus! eu me humilho

Ante a vossa divindade!

Mandai-nos a claridade

Do Espírito Santo.

Enxugai o nosso pranto,

Acalmai nossa discórdia,

Por vossa misericórdia,

Amém, Jesus.

17. Caramuru é a denominação dada pelos farroupilhas aos soldados imperiais. Anteriormente, o termo foi empregado no Rio de Janeiro para designar os membros do Partido Restaurador, favoráveis à volta da coroa portuguesa. 


\section{Persignação Caramuru}

Tristes tempos malfadados

De não vistas maravilhas!

Distinguem-se os farroupilhas

Pelo signal.

De pistola, de punha,

A vaga, raivosa gente

Assola o continente

De Santa Cruz.

Chamam-nos caramurus

Nos ameaçam de saque;

Mas de semelhante ataque

Livre-nos Deus!

As leis andam a boléus

O povo tremendo foge...

Bento Gonçalves é hoje

Nosso senhor!

Os que furtam sem pudor,

Espancam os seus patrícios,

Chamam-se sem artifícios

Dos nossos.

Os que, temendo alvoroços,

Querem viver retirados,

Logo são apelidados

Inimigos. 
Dizem ainda tais amigos

Que há de Caldas ${ }^{18}$ governar,

E que a lei há de ditar

Em nome do Padre.

Não acham leis que lhes agrade,

Senão com a lei dos seus,

Todos abusam de Deus

E do Filho.

Malditos! Em um tornilho

Deve achar-se cada qual,

Com o tormento corporal

Do Espírito Santo.

Assim queira Deus portanto

Que o diabo por esses ares

Carregue o Silva Tavares ${ }^{19}$

Amém, Jesus.

Vagner Camilo é Professor de Literatura Brasileira na Universidade de São Paulo.

18. Referência a padre Caldas, revolucionário da confederação do Equador, que vivia refugiado no Uruguai e mantinha um jornal de ideias republicanas, além de corresponder-se com os comandantes da fronteira, incluindo Bento Gonçalves. Seu nome passou a ser evocado quando, a partir de 1831, começaram a circular boatos sobre uma intenção separatista na província, a fim de uni-la ao Estado Oriental (Uruguai), dizendo-se ainda que, na fronteira, além de se pregar a revolução, prometia-se a liberdade aos escravos. Os adversários da revolução referiam-se a ele como o "indigno Padre Caldas". 19. João da Silva Tavares, barão e visconde de Cerro Alegre, opôs-se aos farroupilhas, tomando o partido dos imperiais, e lutou na Batalha do Seival, da qual saiu derrotado. Depois foi atacado e sitiado perto de Arroio Grande, sendo aprisionado e enviado ao Uruguai. Sob a guarda de certo capitão Menino Diabo, com alguns outros companheiros e sob a ameaça de fuzilamento, conseguiu, em 5 de fevereiro de 1837, fugir e formar uma nova brigada.

166. CAMILO, Vagner. Revoltas provinciais: testemunhos poéticos 